\title{
DEVELOPING OF CALCULUS TEACHING MATERIALS BASED ON AUDIOVISUAL
}

\author{
Akbar Nasrum*1 ${ }^{1}$, Herlina ${ }^{2}$ \\ ${ }^{1,2}$ Universitas Sembilanbelas November Kolaka
}

\begin{tabular}{l}
\hline Article Info \\
\hline Article history: \\
Received August 8, 2019 \\
Revised Sept 21, 2019 \\
Accepted Sept 26, 2019 \\
\hline
\end{tabular}

Keywords:

Audiovisual teaching materials, Learning videos

\begin{abstract}
Millennials community right now prefer video media as a learning resource rather than reading textbooks. To understand the contents of books, we need to have a reasonably high literacy ability. Unlike the case with learning videos, explanations accompanied by images in the video can help someone to understand the material in that media. The first goal of this study was to make audiovisual teaching materials that could serve as a supplementary textbook teaching materials. The second goal was to test the effectiveness of teaching materials that have been created. The method used was the development method using the ADDIE model (Analyze, Design, Development, Implementation, and Evaluation). The process of developing teaching materials began with creating multimedia learning, recording stages, editing stages, and completion stages. Material experts and media experts then validated the teaching materials that had been produced and tried out on students. The results of the try out documents to the students showed that there were significant changes both in terms of motivation, enthusiasm for learning, interaction in the classroom, and from student learning outcomes. These results made the student's response to the use of teaching materials excellent. This audiovisual teaching material was worthy and effectively of being used as a learning media, both as a supplementary or primary source.
\end{abstract}

Copyright (C) 2019 IKIP Siliwangi. All rights reserved.

\section{Corresponding Author:}

Akbar Nasrum,

Department of Mathematics Education,

Universitas Sembilanbelas November Kolaka,

Jl. Pemuda, Kolaka, Southeast Sulawesi 93561, Indonesia.

Email: akbar.nasrum@gmail.com

\section{How to Cite:}

Nasrum, A., \& Herlina, H. (2019). Developing of calculus teaching materials based on audiovisual. Infinity, 8(2), 209-218.

\section{INTRODUCTION}

Calculus is a compulsory subject given to students at the beginning of the semester. Besides being compulsory, this course is essential because the knowledge gained here is the basis for programming advanced Calculus courses, the real analysis I, real analysis II, and differential equations. Even though the material in Calculus is primary material, this course is a scourge of problems for students so that it has an impact on less than optimal learning outcomes (Shodikin, 2017).

In order to obtain maximum learning outcomes, the learning process should be supported by adequate learning facilities and resources, especially in terms of teaching materials. However, the importance of Calculus material is not directly proportional to the 
availability of teaching materials such as Calculus books at the campus library. Students interest in buying books also lacks because the price of this book is quite high. The difficulty of obtaining Calculus teaching materials makes students less than optimal in learning. They only rely on the material obtained during the lecture, even though the density of Calculus material and the limited time of lectures make this material sometimes incomplete. Focusing on the completeness of learning outcomes will cause the learning material to lag. Conversely, pursuing the completion of the material in one semester can lead to incomplete learning outcomes. These two variables are essential to note because they can cause failures in courses that require Calculus basics.

On this basis, we took the initiative to develop Calculus teaching materials from textbooks into audiovisual teaching materials. This teaching material can function as a complement or even replace the role of textbooks as the primary source of teaching materials. The process of making teaching materials involves some software, one of which is GeoGebra software. The representation of the concepts of functions, limits, derivatives, and integrals in Calculus is increasingly easily understood if geometrically explained using GeoGebra (Caligaris, Schivo, \& Romiti, 2015). Besides Takači, Stankov, \& Milanovic (2015) said that using GeoGebra, student learning achievement in checking and drawing function graphics is better than without using it.

Teaching materials in the form of videos can be stored on a mobile device that can be carried anywhere (moving learning) making it easier for students to study anywhere and anytime (Bano, Zowghi, Kearney, Schuck, \& Aubusson, 2018). Besides, they can construct knowledge from independent learning activities carried out using videos so that the process of developing thinking skills for students occurs. Ownership of mobile devices by students supports the creation of outside-class learning using mobile learning (Crompton \& Burke, 2018). The use of video learning in mobile learning is a promising learning strategy, relevant and can improve the quality of education (Forbes et al., 2016). However, it is not an easy thing to make exciting learning videos, so it is still rarely used. It takes its creativity to make teaching videos more exciting and varied (Christ, Arya, \& Chiu, 2017).

Teaching materials in the form of videos can also support YouTube channels as learning tools in education by uploading videos there (Orús et al., 2016). In the era of digital, students tend to prefer to access YouTube to search literature videos or educational videos rather than open textbooks. It is not difficult to find good educational videos. Surfers can use visitor ratings as an indicator to look for good educational videos (Shoufan, 2019).

With this teaching video, students are expected to be able to understand the material more quickly because of the presentation of material in teaching materials in the form of visual and sound (audio). According to Purwanti (2015), video media tends to be easier to remember and understand because it uses two senses, namely the sense of sight and hearing. Unlike the case with a textbook that requires students to read and try to understand the material itself. Apart from that, the explanation of still images in textbooks is explained visually moving on audiovisual teaching materials so that they are easier to understand. The explanation in audiovisual teaching materials is designed to resemble explanations in the classroom. In essence, this teaching material is a combination of textbooks and classroom learning. So, the formulation of the problem in this study, i.e., "Are the audiovisual teaching materials that have been made feasible and effective to be used as learning media? 


\section{METHOD}

This research is development research using the ADDIE model (Nadiyah \& Faaizah, 2015). As the name implies, this model consists of several processes, namely: analyze, design, development, implementation, and evaluation. In the analysis phase, researchers must know the student's ability to learn, student attitudes, the conditions of the facilities and infrastructures used for learning, and others. All factors that cause disparities in learning outcomes must be analyzed in order to design instructional media that are suited to the conditions and abilities of students. In the design phase, information that has been obtained from the analysis phase is used to design learning prototypes. How to choose the right media, design a user interface, design a graphic design or display, so users are not bored, and learning objectives can be achieved. The next stage of development is the stage of teaching material production by integrating all technologies that will be used to achieve learning objectives. In this stage, consultation with material experts and learning design experts is needed. The next stage is implementation. In this stage, prototypes of teaching materials that have been produced and examined by experts are then tested on students and ensuring that students can obtain knowledge and skills from the media used. Finally, the evaluation stage aims to find out the improvement of student competencies, students' attitudes towards learning activities, and the benefits of the instructors with this learning media. This process produces teaching materials produced in the form of learning videos. The research design used to test the effectiveness of this teaching material was one group pre-test post-test design. The effectiveness of instructional materials was tested by taking 48 students of the 4th semester of mathematics education at the University of Sembilanbelas November Kolaka as research subjects. Forty-eight of these students are all 2017 mathematics education students.

Sources of data in this study are learning media experts, material experts, and students. Data were collected using several instruments including in the form of material evaluation instruments by material experts, evaluation instruments for instructional media experts, learning outcome test instruments consisting of pre-tests and post-tests and questionnaires for student responses to the use of instructional materials.

The development of this teaching materials is in dire need of advice from material experts and media experts. In its development, researchers collaborated with material experts and media experts so that the resulting teaching materials could be better. The content focuses on the primary material before entering calculus material, i.e., the introduction of functions. The evaluation results from media experts and material experts are input to improve the quality of teaching materials. Furthermore, to see the effectiveness of these teaching materials, the scores of students' pre and post-test were compared. Besides, the magnitude of the increase can be measured using n-gain values (Marx \& Cummings, 2007). The last, the researcher gave a questionnaire to students was to see how well the students responded to the use of teaching materials.

\section{RESULTS AND DISCUSSION}

Explanation of the results of the following research is two parts. First, it will explain the results of developing teaching materials and then explain the results of the effectiveness of teaching materials. 
Table 1. List of learning video links

\begin{tabular}{cc}
\hline Material Name & Link download \\
\hline Definition of function & $\underline{\mathrm{https}: / / \text { youtu.be/5ACQu7Z87Qc }}$ \\
Linear function I & $\underline{\mathrm{https} / / / \text { youtu.be/e8YKEetJYak }}$ \\
Linear function II & $\underline{\mathrm{https} / / / \text { youtu.be/Hbxr_Jao5Z4 }}$ \\
Quadratic function & $\underline{\mathrm{https}: / / \text { youtu.be/jilM1uHoM88 }}$ \\
Shipting graph & $\underline{\mathrm{https} / / / \text { youtu.be/_auJkiVv64c }}$ \\
Absolute function & $\underline{\text { https://youtu.be/Tew7Wge6Fbk }}$ \\
\hline
\end{tabular}

Table 2. Suggestions for Media Repair by media and material experts

\begin{tabular}{cll}
\hline No. & \multicolumn{1}{c}{ Aspect } & \multicolumn{1}{c}{ Recommendation for Improvement } \\
\hline 1 & Design & Add learning achievements to the media \\
2 & Sounds and & The image quality is at least 720 pixels so that the image \\
& Pictures & quality does not break when enlarged \\
3 & Material quality & The presentation time is too fast \\
4 & Sounds and & There is a mismatch between the speaker's sound and the \\
& Pictures & cursor motion on some videos
\end{tabular}

\subsection{Results}

There are several results obtained after the research is carried out. First, the results obtained from the ADDIE process, i.e., several learning videos that can be download from the link in the Table 1.

The results were obtained through several evaluation processes, both evaluations from material experts and media experts. There are some suggestions for improvement from media experts and material experts in the first stage of evaluation summarized in Table 2. These suggestions provide input for researchers to correct some of the deficiencies that exist in the media.

After revision, a validation sheet is again given to the material expert and media expert for the final evaluation. The results can be seen in Table 3 and Table 4.

Teaching materials that have been made through a consultation process from two expert fields are then tested on a limited basis. Two students were taken from the category of a high, medium, and low learning outcomes as a small sample. After media testing on these students, almost no significant problems were found. Only the problem of slow understanding of students with low learning outcomes. However, the problem can be solved in a class by re-explaining material that is not understood.

Table 3. Score of the feasibility of learning videos by media experts

\begin{tabular}{clcc}
\hline \multirow{2}{*}{ No. } & \multirow{2}{*}{ Aspect } & \multicolumn{2}{c}{ Score } \\
\cline { 3 - 4 } & & Media expert I & Media expert II \\
\hline 1 & Design & 4.25 & 4.00 \\
2 & Sounds and Pictures & 4.60 & 4.40 \\
3 & Software engineering & $\mathbf{4 . 2 8}$ & 4.00 \\
\hline \multicolumn{2}{c}{ Mean } & & $\mathbf{4 . 1 3}$ \\
\hline
\end{tabular}


Table 4. The score of learning video eligibility by material experts

\begin{tabular}{clcc}
\hline \multirow{2}{*}{ No. } & \multicolumn{1}{c}{ Aspect } & \multicolumn{2}{c}{ Score } \\
\cline { 3 - 4 } & & Material expert I & Material expert II \\
\hline 1 & Material relevance with syllabus & 4.67 & 4.67 \\
2 & Material Quality & 4.00 & 4.40 \\
3 & Language Aspect (sound) & 4.00 & 4.00 \\
4 & Functions and benefits & 4.00 & 4.33 \\
\hline \multicolumn{2}{c}{ Mean } & $\mathbf{4 . 1 7}$ & $\mathbf{4 . 3 5}$
\end{tabular}

After limited trials have been conducted, audiovisual teaching materials are ready to be implemented in large classes. Forty-eight registered students were used as research subjects but only forty-four people who actively participated in lectures. The final results of the application of media in large classes can be seen in Figure 1.

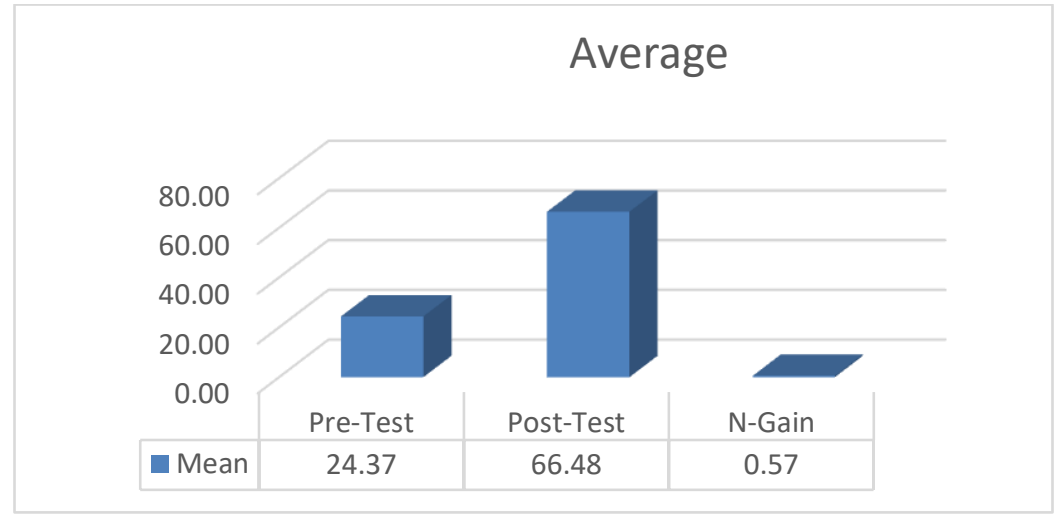

Figure 1. The average pre-test, post-test, and n-gain

Besides, to see student responses to the use of instructional video media, a closed questionnaire was given. The results of questionnaire data processing can be seen in the Table 5.

Table 5. Student responses to the use of media

\begin{tabular}{clccc}
\hline \multirow{2}{*}{ No } & \multirow{2}{*}{ Indicator } & \multicolumn{3}{c}{ Category } \\
\cline { 3 - 5 } & & High & Medium & Low \\
\hline 1 & Feeling happy & $68.18 \%$ & $31.82 \%$ & $0.00 \%$ \\
2 & Ease of understanding material & $78.79 \%$ & $17.42 \%$ & $3.79 \%$ \\
3 & Motivation to follow lessons & $68.18 \%$ & $31.82 \%$ & $0.00 \%$ \\
4 & Active in the learning process & $63.64 \%$ & $18.18 \%$ & $18.18 \%$ \\
5 & Influence on results & $45.45 \%$ & $50.00 \%$ & $4.55 \%$ \\
6 & Interest & $97.73 \%$ & $2.27 \%$ & $0.00 \%$ \\
\hline
\end{tabular}




\subsection{Discussion}

\subsubsection{Analyze}

The primary ability of student Calculus that researchers pay attention from year to year is the basis for making audiovisual teaching materials. Advanced Calculus courses, the real analysis I, real analysis II, and differential equations cannot be taught without this essential knowledge. Repeating that fundamental concept in the classroom certainly takes much time so that an appropriate method is needed so that the lecture process is not interrupted. Video learning is one of the best choices in various methods. By using video learning media, teaching and learning process can run more effectively. This is consistent with the results of research from Nurdin et al. (2019) which says that learning videos were effective and have a positive effect on improving students' understanding of mathematical concepts. Video media will also help teachers to make it easier to deliver material and create learning situations that are not monotonous and will help make it easier for students to understand the material (Kurniawan, Kuswandi, \& Husna, 2018). Because the abilities in class vary, videos are designed in such a way that even people who are unfamiliar with mathematics can easily understand the material presented.

\subsubsection{Design}

These design aspects include video design, video format, and video content. These three aspects are adjusted to the needs based on the results at the analysis stage. In terms of video design and video format, it involves some software, i.e., powerpoint, GeoGebra, Camtasia recorder 8.0, and Camtasia Studio 8.4. The process of display design and animation is made using powerpoint. Geogebra software is a complement in explaining Calculus material, Camtasia recorder is used to record videos, and Camtasia studio is used to edit videos and convert recordings to mp4 videos. Examples of design and video editing stages can be seen in Figure 2.

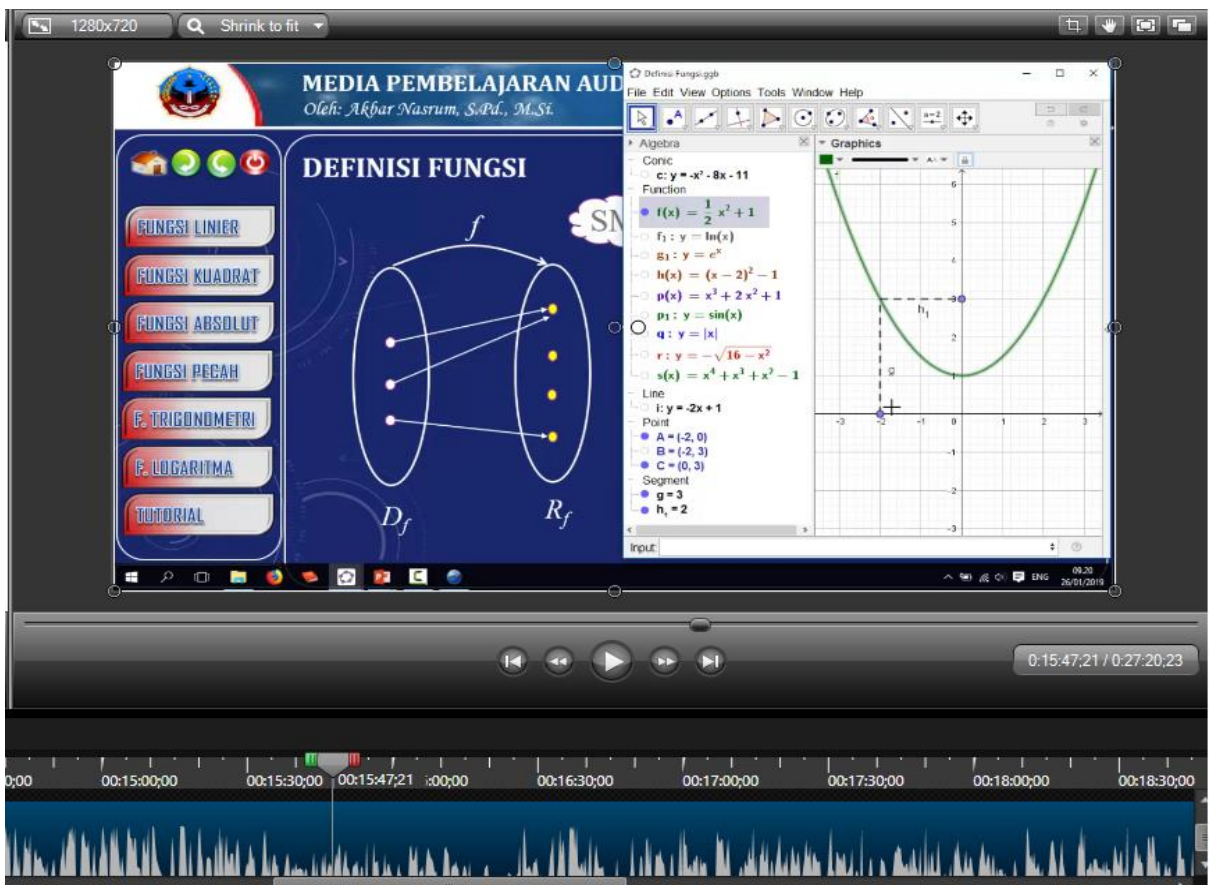

Figure 2. Design and video editing processes 
The GeoGebra seen in the video media in Figure 2 is used to facilitate the explanation of Calculus materials, especially those related to functional materials. The ease of understanding the material explained by using Geogebra is a unique attraction for students. This is consistent with the study of Trung (2014) which shows that about $79 \%$ of students from the total population studied often use GeoGebra software independently without being instructed by the teacher to recheck their knowledge. According to Fitriyani, (2012), Geogebra can also increase student activity and learning outcomes. The use of Geogebra is arranging so that it does not interfere with the appearance in the video.

After going through the editing process, it finally arrived at the final stage. The final stage produces mp4 videos with 720-pixel quality and uploaded to youtube. This video was set so that search engines can not find it on YouTube. The reason was that learning videos were distributed to students according to the schedule set by the lecturer. Learning videos in this study were necessary materials that must be well understood by students before entering the core material from Calculus. We are still developing similar teaching videos for further research.

\subsubsection{Development}

The process of developing teaching materials involves several experts, i.e., two material experts and two instructional media experts. As the first learning media expert, Mr. Kadaruddin, S.Pd., M.Pd was chosen who was an expert in the field of learning media while the second media expert was Mr. Sufri Mashuri, S.Pd., M.Pd. He is a Calculus lecturer in the mathematics education study program and also experienced in learning media, so he was chosen as a material expert and media expert. Other lecturers who are interested in becoming material experts are Mr. Ansar, S.Si., M.Sc who is a Calculus lecturer in the Faculty of Engineering University of Sembilanbelas November Kolaka. The evaluation values of the three experts were input into developing learning videos.

There are some suggestions for improvement from media experts and material experts at the first stage of evaluation summarized in Table 2. These suggestions are input for researchers to correct some of the shortcomings in the media. After revision, a validation sheet is again given to the material expert and media expert for the final evaluation. The results can be seen in Table 3 and Table 4 .

Based on Table 3, the average value of each aspect both from the first expert and the second expert is not less than four (the scale of one to five). That is, in terms of the feasibility of the video media, it is declared appropriate to be used as a learning media. While in terms of material, the results of the evaluation can be seen in Table 4.

Based on Table 4, the average value of each aspect assessed is almost the same as the assessment of media experts. From the evaluation of two material experts, the average score given by each aspect was not less than 4, which meant that the learning videos from the material side were very valid (Farman \& Yusryanto, 2018). Thus, because the video has been validated and declared feasible, the learning video can already be used.

\subsubsection{Implementation}

The process of implementing media in large class was carried out after the initial test was given. Video media is given to students to watch and learn independently. When the lecture time arrives, the teacher needs to ask which part of the video was difficult to understand. Sometimes from some material given, only a small portion is poorly understood, so it needs a few minutes of explanation. The learning process in the 
classroom becomes more active because students are prepared with material that has been studied earlier. Another advantage does not require much time to explain the material taught on that day so that the use of teaching time is more efficient.

The lecture process like this was done for four weeks, and the final results can be seen in Figure 1. Comparison of the average results of the pre and post-test was very significant. These results indicate that the use of audiovisual media can influence on improving learning outcomes. It supported with research conducted by Asmara (2015) which says that student learning outcomes using audiovisual learning media are better than not using audiovisual. Although not measured in detail, from the way to answer the questions given, it appears that understanding the concept of material after the use of the media for the better. It supported by research conducted by Utami, (2013) and Nurdin et al. (2019) who say that learning by using audiovisual media can improve understanding of material concepts for students. The quality of learning outcomes can be seen from the magnitude of the $\mathrm{n}$-gain value. The value of 0.57 was included in the category of "moderate" improvement. (Hake, 1998).

\subsubsection{Evaluation}

From the whole series of process of developing teaching materials, starting from designing to the implementation stage, it has been through various types of evaluation stages, starting from evaluating media experts and material experts to evaluating the use of video media itself. Finally, an open questionnaire was given to students to see how much they responded to the use of this video media.

Based on Table 5, there are six indicators assessed. First, from the results of research on student responses, $68.18 \%$ of students were happy to learn mathematics using audiovisual media, and $31.82 \%$ were mediocre. $78.79 \%$ of students can quickly receive lessons, $17.42 \%$ are mediocre, and $3.79 \%$ of students still do not understand sometimes. $63.64 \%$ of students became more active in receiving lessons, $18.18 \%$ were less active, and the remaining $18.18 \%$ were inactive. $68.18 \%$ of students are very motivated to follow the lessons and $31.82 \%$ are mediocre. The influence of the use of media on learning outcomes can also be seen in Table 5. There are about $45.45 \%$ of students whose learning outcomes are getting better, $50 \%$ of students who have moderate learning outcomes and $4.55 \%$ who have still poor learning outcomes.

Although the data above varies, for the sixth indicator $97.73 \%$ of students expressed interest in following the lesson if it were implemented learning using audiovisual learning media like this and only $2.27 \%$ or one less interested person. The result from indicator six shows the positive response given by students towards the use of this media.

\section{CONCLUSION}

From the results of the study, several conclusions can be drawn i.e., We have succeeded in making audiovisual-based learning media that have been validated by media experts and material experts in good categories so that the media can be used as learning material both for primary sources and as a complement to textbooks. The use of audiovisual media can be more beneficial in terms of time management because it does not take much time to explain the material in the video. In addition to being efficient, the use of media has an effect on activeness in the classroom and is also very effectively used in improving student learning outcomes. 


\section{ACKNOWLEDGEMENTS}

We would like to thank University of Sembilanbelas November Kolaka that funded this research through the scheme internal "Penelitian Dosen Pemula" 2018.

\section{REFERENCES}

Asmara, A. P. (2015). Pengembangan media pembelajaran berbasis audio visual tentang pembuatan koloid. JURNAL ILMIAH DIDAKTIKA: Media Ilmiah Pendidikan dan Pengajaran, 15(2), 156-178.

Bano, M., Zowghi, D., Kearney, M., Schuck, S., \& Aubusson, P. (2018). Mobile learning for science and mathematics school education: A systematic review of empirical evidence. Computers \& Education, 121, 30-58.

Caligaris, M. G., Schivo, M. E., \& Romiti, M. R. (2015). Calculus \& GeoGebra, an interesting partnership. Procedia-Social and Behavioral Sciences, 174, 1183-1188.

Christ, T., Arya, P., \& Chiu, M. M. (2017). Video use in teacher education: An international survey of practices. Teaching and Teacher Education, 63, 22-35.

Crompton, H., \& Burke, D. (2018). The use of mobile learning in higher education: A systematic review. Computers \& Education, 123, 53-64.

Farman, F., \& Yusryanto, Y. (2018). Pengembangan desain pembelajaran berbasis problem posing dalam upaya meningkatkan kemampuan penalaran konsep lingkaran pada siswa SMP kelas VIII. Jurnal Karya Pendidikan Matematika, 5(2), 20-27.

Fitriyani, W. (2012). Pemanfaatan Software Geogebra Melalui Strategi Ideal pada Materi Sudut Pusat dan Sudut Keliling Lingkaran Untuk Meningkatkan Keaktifan dan Hasil Belajar Siswa Kelas VIII F SMP Negeri 3 Pati Tahun Pelajaran 2011/2012. In Prosiding Seminar Nasional Matematika dan Pendidikan Matematika. Yogyakarta: Jurusan Pendidikan Matematika Universitas Negeri Yogyakarta.

Forbes, H., Oprescu, F. I., Downer, T., Phillips, N. M., McTier, L., Lord, B., ... \& Simbag, V. (2016). Use of videos to support teaching and learning of clinical skills in nursing education: A review. Nurse education today, 42, 53-56.

Hake, R. R. (1998). Interactive-engagement versus traditional methods: A six-thousandstudent survey of mechanics test data for introductory physics courses. American journal of Physics, 66(1), 64-74.

Kurniawan, D. C., Kuswandi, D., \& Husna, A. (2018). Pengembangan media video pembelajaran pada mata pelajaran IPA tentang sifat dan perubahan wujud benda kelas IV SDN Merjosari 5 Malang. JURNAL INOVASI DAN TEKNOLOGI PEMBELAJARAN, 4(2).

Marx, J. D., \& Cummings, K. (2007). Normalized change. American Journal of Physics, 75(1), 87-91.

Nurdin, E., Ma'aruf, A., Amir, Z., Risnawati, R., Noviarni, N., \& Azmi, M. P. (2019). Pemanfaatan video pembelajaran berbasis Geogebra untuk meningkatkan kemampuan pemahaman konsep matematis siswa SMK. Jurnal Riset Pendidikan Matematika, 6(1). 
Orús, C., Barlés, M. J., Belanche, D., Casaló, L., Fraj, E., \& Gurrea, R. (2016). The use of YouTube as a tool for learner-generated content: Effects on students' learning outcomes and satisfaction. Computers \& Education, 95, 254-269.

Purwanti, B. (2015). Pengembangan media video pembelajaran matematika dengan model assure. Jurnal Kebijakan dan Pengembangan Pendidikan, 3(1), 42-47.

Nadiyah, R. S., \& Faaizah, S. (2015). The development of online project based collaborative learning using ADDIE Model. Procedia-Social and Behavioral Sciences, 195, 1803-1812.

Shodikin, A. (2017). Pengembangan Bahan Ajar Kalkulus Integral Berbasis Animasi. Aksioma: Jurnal Program Studi Pendidikan Matematika, 6(1), 1-11.

Shoufan, A. (2019). What motivates university students to like or dislike an educational online video? A sentimental framework. Computers \& Education, 134, 132-144.

Takači, D., Stankov, G., \& Milanovic, I. (2015). Efficiency of learning environment using GeoGebra when calculus contents are learned in collaborative groups. Computers \& Education, 82, 421-431.

Trung, T. (2014). Discovery learning with the help of the geogebra dynamic geometry software. International Journal of Learning, Teaching and Educational Research, 7(1), 44-57.

Utami, K. (2013). Penggunaan media audio visual untuk meningkatkan pemahaman konsep siswa di Sekolah Dasar. Jurnal Penelitian Pendidikan Guru Sekolah Dasar, 1(2), 1-10. 